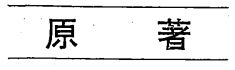

\title{
腸炎ビブリオの $\mathrm{K}$ 抗原に関する研究
}

\section{-1. $\mathrm{O} 2: \mathrm{K} 3$ および $\mathrm{O} 2: \mathrm{K} 28 \mathrm{~K}$ 抗原の免疫学的特異性とその糖構成——}

\author{
工 藤 泰 雄 \\ 東京都立衛生研究所 細菌部 (部長 : 善養寺浩) \\ 〔受付：1月 23 日, 1969年〕
}

腸炎ビブリオは，O抗原のほかに，さらに生菌の O凝 集反応を阻止する萊膜 $(K)$ 抗原を有することが知られ ている(滝川ら，1959）。このK抗原はO抗原と同様に 型特異性を有すること,さらにO抗原と密接に相関して いることから，現在本菌の型別に広く利用されている (坂崎, 1963)。このK抗原を免疫学的および化学的に追 求することは，K抗原それ自体の役割を知るうえに，ま た，その型特異性を化学的に理解するうえにもきわめて 重要なことであるが，この方面に関する研究はほとんど なされていない。

大腸菌の K抗原については, すでにWiley et al.(1958), Akashi et al. (1964), Ørskov et al. (1963), Jann et al. (1965, 1966), Hungerer, et al. (1967) によつて検討 がなされている。それらの研究によれば，K抗原の本態 はいずれも酸性多糖体であることが示され，このK抗原 は，O抗原とは化学的性状および免疫学的性状のいずれ においても，明らかに区別される。特に Jann et al. (1965, 1966), Hungerer et al. (1967) は, 大腸菌 K抗原 の化学構造についても検討を加兑, この酸性多糖体は, いずれもへキスウロン酸と数種の単糖類からなるオリゴ サッカライド単位の，くり返し構造であること明らか にした。

腸炎ビブリオの $\mathrm{K}$ 抗原については, Omori et al.(1966) が $05: \mathrm{K} 15$ の 1 菌株について検討を加え, 本菌 $\mathrm{K}$ 抗原 も大腸菌 $\mathrm{K}$ 抗原と同様に, 酸性多糖体であることを報告 している。しかし，すべての本菌 $\mathrm{K}$ 抗原が同一の性状を 示すものであるか否か，この成績からでは明らかでな い。

そこで著者は, 現在血清学的に分類されている腸炎ビ ブリオ各K抗原の本態を明らかにするとともに, 血清学 的型特異性を化学構造のうえから追求しょうと考えた。

本報では, $\mathrm{O} 2$ 群に属する $\mathrm{K} 3$ および $\mathrm{K} 28$ の 2 種の $\mathrm{K}$ 抗原について, 化学的, 免疫学的に検討した成績につい
て述べる。

\section{実験材料および方法}

1. 供試菌株

腸炎ビブリオ中津川株（血清型 $\mathrm{O} 2 ： \mathrm{~K} 3$ ), およびT1698 株（血清型O2：K28）を用いた。中津川株は，腸 炎ビブリオ食中毒患者剖検例 (Okudaira et al., 1962) の小腸内容から分離した菌株であり, T-1698 株は, 腸 炎ビブリオ食中毒発生時の, 原因施設のマナイタふき取 りから検出したもので, 両菌株とも当研究所で分離後, ただちに凍結乾燥保存したものである。

2. 免疫血清の調製法

1) 抗 $K O$ 血清

中津川株およびT-1698 株の $3 \%$ 食塩加カンテン培地 $37^{\circ} \mathrm{C}, 18 \sim 24$ 時間培養菌を, $0.5 \%$ ホルマリン加生理食 塩液に $1 \mathrm{mg} / \mathrm{m} l$ の割合に浮遊させ, $37^{\circ} \mathrm{C} に 1$ 夜おいて 完全に殺菌したものを, 免疫用抗原とした。免疫方法は 体重 $2.0 \sim 2.5 \mathrm{~kg}$ のウサギ耳静脈に, 4 日閒隔で初回 $0.5 \mathrm{~m} l$, ついで $1.0 \mathrm{~m} l, 2.0 \mathrm{~m} l, 4.0 \mathrm{~m} l, 4.0 \mathrm{~m} l, 4.0 \mathrm{~m} l$, $4.0 \mathrm{~m} l$, と 7 回接種した。最終接種から 7 日後に採血し, 常法によつて血清を採取し, $56^{\circ} \mathrm{C}, 30$ 分間不活化後使 用した。

抗K O 血清の凝集素価は, 免疫に用いた菌株の生菌に 対して $1: 1,280,100^{\circ} \mathrm{C}, 2$ 時間加熱菌に対して 1 : 640以上のものを使用した。

2) 抗 $O$ 血清

前記抗 $\mathrm{K} O$ 血清作成の場合と同様に, 生理食塩液に $1 \mathrm{mg} / \mathrm{m} l$ の割合で浮遊させた菌を, $100^{\circ} \mathrm{C}, 2.5$ 時間加熱 後, 生理食塩液で 3 回洗浄し, 生理食塩液に $1 \mathrm{mg} / \mathrm{ml}$ の 割合に再浮遊させたものを免疫原とした。免疫方法およ び接種量は, 抗 $\mathrm{K} O$ 血清作成の場合と同様に行なつた。

抗O血清の凝集素価は, 免疫に用いた菌株の加熱死菌 に対して $1: 1,280$ 以上のものを用いた。 


\section{3）抗K血清}

K3 因子血清は, 中津川株の抗 K O 血清加ら, 同一 $\mathrm{O}$ 抗原でK抗原が異なるT-1698株の加熱菌で吸収して作 成した。

まず抗 $\mathrm{K} O$ 血清を生理食塩液で 5 倍に希釈し, その 10 $\mathrm{m} l$ に対して $\mathrm{T}-1698$ 株のカンテン培地培養菌約 2,000 $\mathrm{mg}$ を加え, $37^{\circ} \mathrm{C}, 2$ 時間作用させたのち 1 夜水室に放 置し, 10,000 r.p.m. 15 分間遠心沈殿して吸収菌を除去 し，その上清について凝集反応によつてO抗体の有無を 調べた。O抗体の吸収不完全な場合は, 再び前記同様な 操作をくりかえし，O抗体を完全に吸収した。

K28 因子血清の調製は， T-1698株の K O 血清を吸収 菌として中津川株を用い，前記の K 3 因子血清の調製と 同じ要領で作成した。

こうして得た抗 K血清の凝集素価は, 対応生菌に対し て $1: 64$ 以上であり，それぞれの加熱死菌に対して 20 倍以下であつた。

3. 抽出 $\mathrm{K}$ 抗原の免疫学的分析

1） カンテン・ゲル内沈降反応

Ouchterlony (1949) の方法に従つて行なつた。反応 させたカンテン平板は, 密閉湿室中で $37^{\circ} \mathrm{C}$ に保ち, 2 7 日間観察した。

\section{2) 免疫電気泳動}

$\mathrm{pH} 6.3$ リン酸緩衝液および $\mathrm{pH} 8.3$ ホウ酸緩衝液に カンテン末を $1.2 \%$ の割合に加え, 溶解後さらにチメロ サールを $0.01 \%$ の割合に加えたカンテン・ゲルを支持 体として用いた。泳動は，原点のくぼみに抗原を注入し $1.3 \mathrm{~mA} / \mathrm{cm}, 200 \mathrm{~V}$ の条件で $2 \sim 2.5$ 時間 $4^{\circ} \mathrm{C}$ で行なつ た。泳動後側溝に抗血清を加え, $37^{\circ} \mathrm{C}$ 湿室中におき沈 降線を観察した。

\section{4. ゾーン電気泳動}

$1 \times 1 \times 40 \mathrm{~cm}$ セルを用い，バレイショデンプンを支持 体として pH 8.3 小ウ酸緩衝液で $4^{\circ} \mathrm{C}, 18$ 時間泳動し た。泳動条件は $320 \mathrm{~V}, 25 \mathrm{~mA}$ で, 泳動終了後デンプン ブロックを $1 \mathrm{~cm}$ 幅に切断し, 各断片を精製水で抽出し たのち, 各抽出液について炭水化物, 核酸およびK抗原 活性をそれぞれ測定した。

\section{5. 化学分析}

窒素はミクロケールダール法 (Kabat and Mayer, 1961a), リンは Allen の中村変法 (1950), タンパクは Folin-Lowry 法 (Lowry, 1951) およびミクロビュレッ ト法（菅原，1966）によりそれぞれ測定した。総炭水化 物は, Dische (1947) のトリプトファン硫酸反応（グル コース標準）により，メチルペントースは, Dische お
よび Shettles (1948) のシスティン硫酸反応（ラムノー ス標準)により測定した。

アミノ糖は, 試料を $4 \mathrm{~N}-\mathrm{HCl}$ で 6 時閒加水分解したの ち, Elson-Morgan 法 (Belcher, 1954) で測定した。へプ トースは, Dische のシスティン硫酸反応の Osborn 変法 (1963), ウロン酸は, Dische のカルバゾール硫酸反応 (Aschwell, 1957), シアリン酸は, Warren (1959)のチ オバルビッール酸法により, それぞれ定性的に分析し た。KDO (2-keto-3-deoxy octonic acid) は, 試料を 0.02 $\mathrm{N}-\mathrm{H}_{2} \mathrm{SO}_{4}$ で $100^{\circ} \mathrm{C}, 20$ 分間加水分解後, Osborn (1963) のチオバルビッール酸変法, および Dische のシスティ ン硫酸反応の Osborn 変法 (1963) によつて定性的に分 析した。核酸 (DNA) は, Diphenylamine 法 (Kabat and Mayer, 1961 b), および日立分光光度計 EPU-2 型 による紫外部 $260 \mathrm{~m} \mu$ 吸収により測定した。

\section{6. 構成糖の分析}

中性糖は, 試料 $20 \mathrm{mg}$ に $1 \mathrm{~N}-\mathrm{H}_{2} \mathrm{SO}_{4} 2 \mathrm{ml}$ を加えて, 封管中 $100^{\circ} \mathrm{C}, 2$ 時間加水分解し, $\mathrm{BaCO}_{3}$ あるいは陰イ オン交換樹脂 (Amberlite IRA-410 $\mathrm{HCO}_{3}^{-}$- 型) で中和 後, ペーパークロマトグラフィー (PPC), および薄層ク ロマトグラフィー（TLC）により分析した。

PPC は東洋濾紙 No. 51 を用い, 下降法によつて行な つた。溶媒系は，i）ピリジンーn-ブタノール-水 (4:6: 3), ii) ピリジンー酢酸エチルー酢酸一水 $(5: 5: 1: 3)$ の 2 種を用い, 糖は, アルカリ性硝酸銀試液, およびアニ リン水素フタール酸塩試液で発色させた。

TLC は吸着剤として Kieselgel G (Merck Co., Ltd., Germany)-亜硫酸水素塩 (Adachi, 1965), 溶媒系は nプロパノール-水 $(8.5: 1.5)$ を用いた。糖の発色は, チモール硫酸試液によつた。

アミノ糖は, 試料 $30 \mathrm{mg}$ に $4 \mathrm{~N}-\mathrm{HCl} 3 \mathrm{ml}$ を加えて封管 中 $100^{\circ} \mathrm{C}, 6$ 時間水解し， $\mathrm{P}_{2} \mathrm{O}_{5}$ および $\mathrm{NaOH}$ 上で減圧 乾燥後, PPC, TLC およびアミ)酸アナライザー（日立 KLA-3B 形) によつて分析した。PPC（東洋濾紙 No. 51) および TLC (Cellulose MN 300 : Marcherry and Nagel Co., Ltd., Germany) とも, 中性糖と同一の溶媒 で展開し，アミノ糖は，ニンヒドリン試液により発色さ せた。

検出糖の同定は，標準糖との Rf の異同，および発色 の色調の比較により行なつた。

\section{7. マウス致死毒性}

凍結乾燥標品の一定量を, 生理食塩液で倍数希釈し, その $0.5 \mathrm{ml}$ ずつを 1 群 5 頭の dd 系マウス（体重約 15 g) の腹腔内に接種し, マウスの生死を 2 日間観察した。 


\section{実 験 成 績}

1. 中津川株 (O2: K3) からのK抗原の抽出および 精製

図 1 に示すように, Westphal et al. (1952) のフェノ 一ル水法に準拠して，K抗原の抽出・精製を行なつた。

すなわち, 供試菌株を 3 \%食塩加カンテン培地平板で $37^{\circ} \mathrm{C}, 18 \sim 20$ 時閒培養を行ない, 菌苔をかきとつて, $3 \%$ 食塩液で洗浄後, $0.025 \mathrm{M}$ トス・塩酸緩衝液 $(\mathrm{pH}$ 8.0 )に約 $10 \mathrm{mg} / \mathrm{m} l$ の割合に浮遊させ，等量の $90 \%$ フ ェノールを添加, $65^{\circ} \sim 68^{\circ} \mathrm{C}, 30$ 分処理した。1 夜 $5^{\circ} \mathrm{C}$ に放置後, 遠心沈殿を行なうと, 少量の水層と多量の粘 ちような中間層を生じた。そこで, 水層を分離したのち 残部に等量のトリス・塩酸緩衝液を加えて再抽出を行な い,こうして得られた水層を初回の水層と合併し, 粗抽 出K抗原とした。この水層画分は, ゲル内沈降反応によ る抗原分析，紫外部吸収において，K抗原，O抗原さら に核酸 (260 $\mathrm{m} \mu$ 吸収物質) を含むことから，さらにK抗 原の精製を行なつた。除核酸のために, Scott ら (1960) の Cetavlon 処理, Sephadexによる gel filtration など
を行なつたが，じゅうぶんな分別ができなかつた。そこ で, 来住 (1965) の凍結融解法により, 核酸の除去を試 みた。まず，水層画分をー $25^{\circ} \mathrm{C}$ で涷結し， 48 時間放置 後室温で融解すると, 核酸はゼリ一状の沈殿として除か れ，K抗原およびO抗原のみを含む上清画分が得られ た。

本画分を減圧濃縮した後, $100,000 \times \mathrm{g}, 4$ 時間の超遠 心を行なうと， $\mathrm{O}$ 抗原は沈渣の部分に， $\mathrm{K}$ 抗原物質は上 清の部分に移行したので, その上清画分を再度超遠心し て，K抗原を精製した。最終的に得られた上清画分を精 製水で透析後凍結乾燥し，K抗原標品とした。この凍結 乾燥標品は白色雲母状で, その水溶液は無色透明で, 粘 ちよう性を呈する。

本標品の收量は, 菌体の乾燥重量当たり約 $5 \%$ であつ た。

2. T-1698 株 (O2：K28) からのK抗原の抽出・精 製

中津川株と同じ方法に従つて $\mathrm{K}$ 抗原を抽出 ・ 精製し た。本菌株の $\mathrm{K}$ 抗原標品も, 中津川株同様, 白色雲母状 を呈し, 水にゆつくりと溶解して, 無色・粘ちよう性の

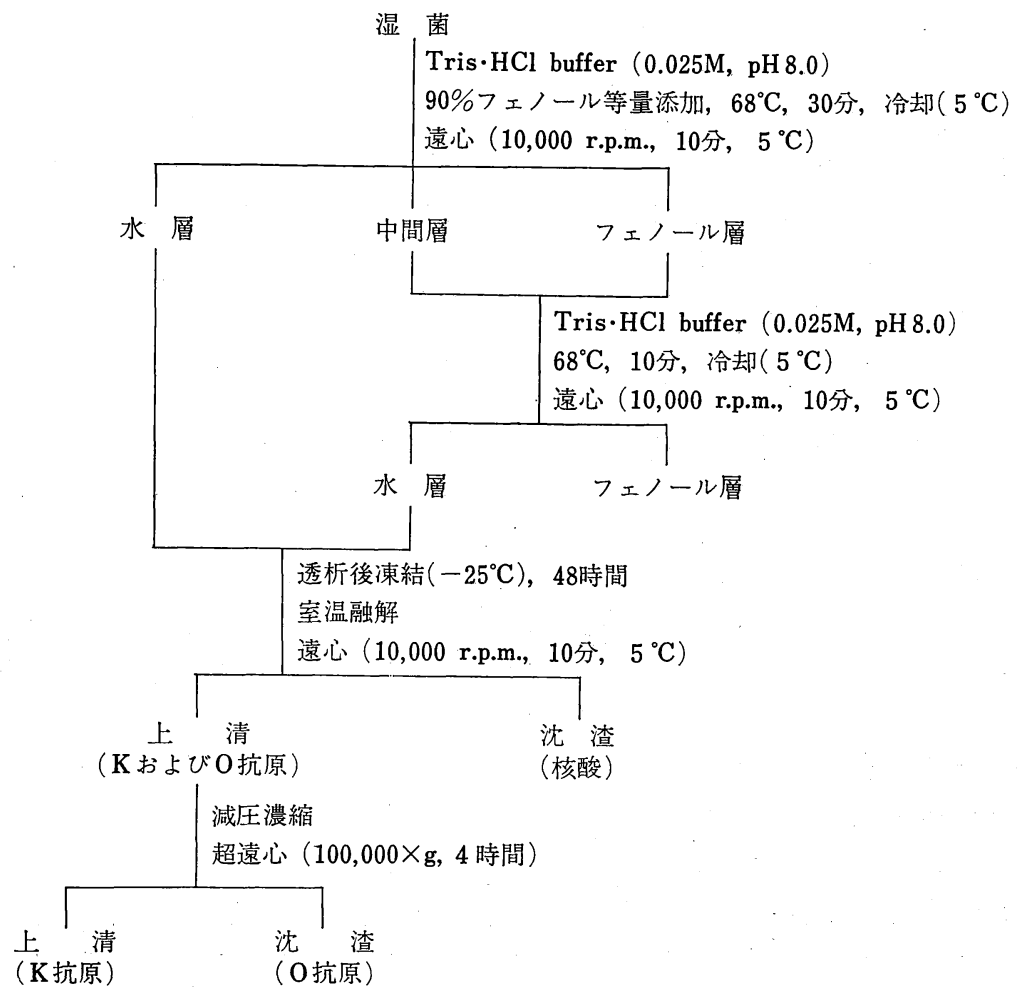

図 $1 \mathrm{~K}$ 抗原の抽出, 精製過程 
水溶液を生ずる。その収量は, 出発菌体の乾燥重量当た り約 $6 \%$ であつた。

\section{3. 抽出 $\mathrm{K}$ 抗原の免疫学的分析}

まず，抽出した K 3 およびK 28 抗原の免疫学的性状を Ouchterlony のゲル内沈降反応および免疫電気泳動に より分析した。

K3 抗原はゲル内沈降反応において，対匛 $\mathrm{KO}$ 血清お よびK血清と互いに融合する 2 本の沈降線を形成したが O血清とは反応しなかつた。また，K28 抗原も K 3 抗原 と同様に，対応 $\mathrm{K} \mathrm{O}$ 血清抢よびK血清と共通の 2 本の沈 降線を形成したが，O血清とは反応しなかつた。したが つて，両K抗原と対応するK O 血清との間に認められる 2 本の沈降線は，いずれも $\mathrm{K}$ 抗原と $\mathrm{K}$ 抗体との反応を示 すものであり，両 $\mathrm{K}$ 抗原は，抗原的にK抗原のみを含み O抗原等他の抗原物質を含んでいないといえる。

また，両K抗原は，図 2 および図 3 に示したようにゲ ル内沈降反応, 免疫電気泳動いずれにおいても, 対応血 清とのみ沈降線を形成する。このことは，この沈降線が

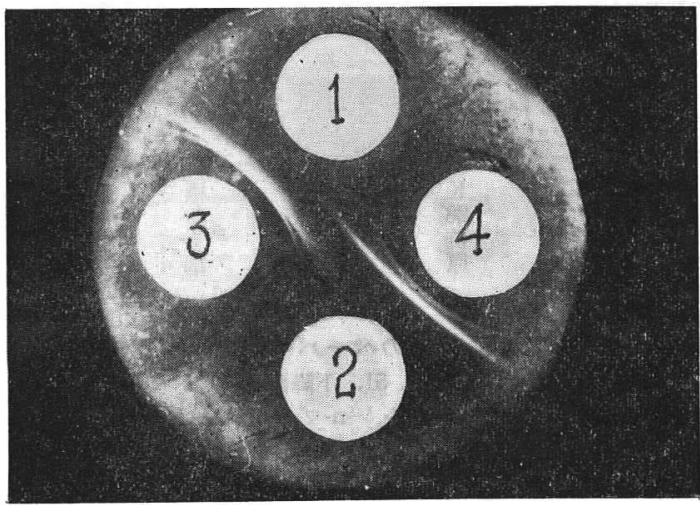

図 2 抽出 $\mathrm{K}$ 抗原のゲル內沈降反応

1. $\mathrm{O} 2: \mathrm{K} 3$ 抗 $\mathrm{KO}$ 血清

2. $\mathrm{O} 2: \mathrm{K} 28$ 抗 $\mathrm{KO}$ 血清

3. $\mathrm{K} 3$ 抗原 $1 \mathrm{mg} / \mathrm{m} l$

4. $\mathrm{K} 28$ 抗原 $1 \mathrm{mg} \mathrm{m} l$
それぞれ凝集反応で示されると同じく，K3 および K 28 の特異的沈降線であることを示するのである。また, 図 3 に示したように両 $\mathrm{K}$ 抗原は, 免疫電気泳動で陽極側に 移動することから，両 $\mathrm{K}$ 抗原はともに酸性物質であると いえる。

つぎに，両K抗原の抗原活性をゲル内沈降反応により 検討すると，両K抗原ともきわめて高い抗原活性を有し $\mathrm{K} 3$ 抗原では抗原希釈 $10 \gamma / \mathrm{m} l$ まで, $\mathrm{K} 28$ 抗原は $20 \gamma /$ $\mathrm{m} l$ まで, 沈降線を形成しうることが認められた。

4. 抽出 $\mathrm{K}$ 抗原の化学的分析

$\mathrm{K} 3$ およびK 28 抗原の紫外部吸収, 化学組成を検討し た成績を，図 4 および表 1 に示した。図から明らかなよ うに, K3 抗原は紫外部の特異吸収が認められないが, K 28 抗原では, 核酸の混在によると思われる $260 \mathrm{~m} \mu$ の 吸収が認められる。

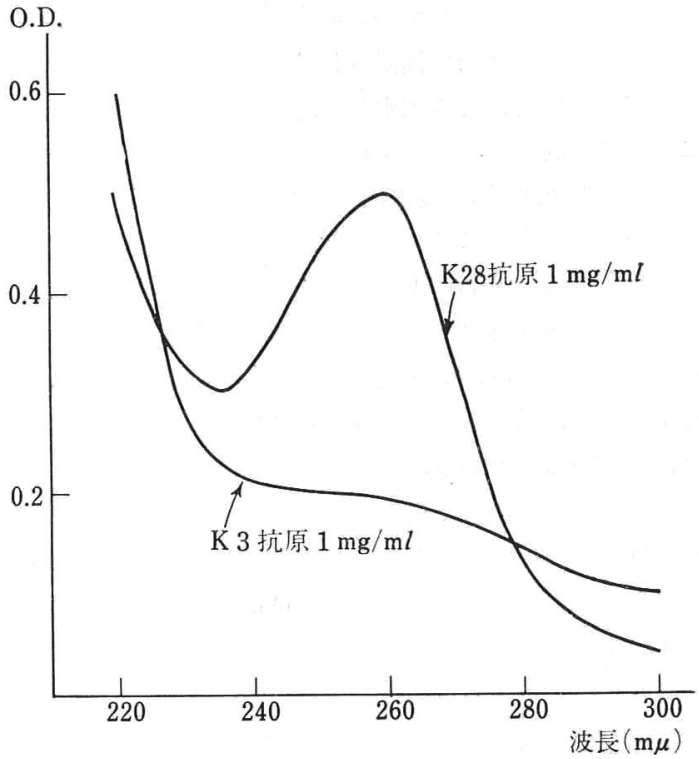

図 4 抽出 $\mathrm{K}$ 抗原の紫外部吸収

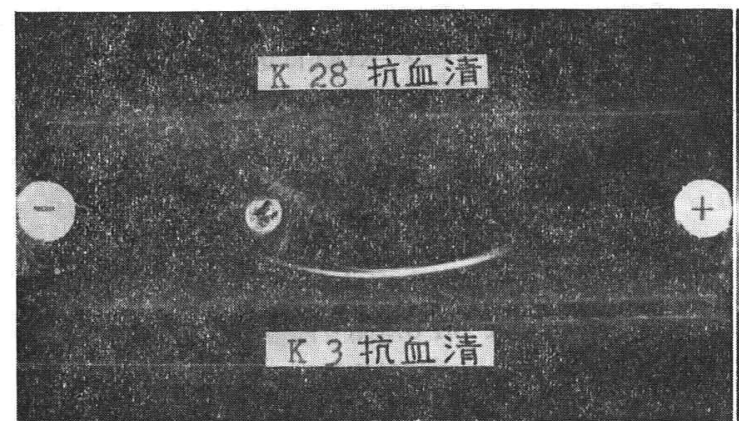

K 3 抗原

図 3 抽出 $\mathbf{K}$ 抗原の免疫電気泳動

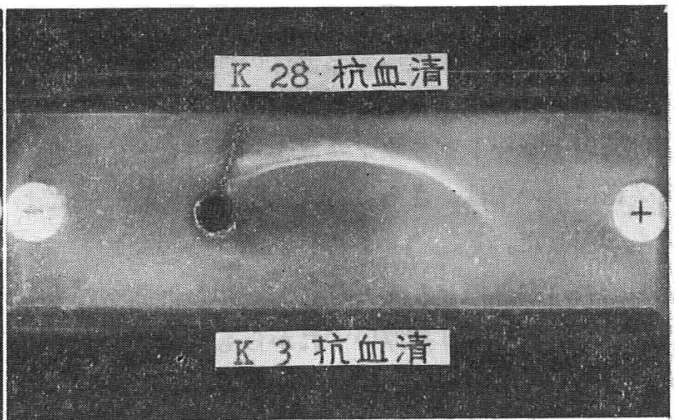

K 28 抗原 
表 1 抽出 $\mathrm{K}$ 抗原および $O$ 抗原の化学組織

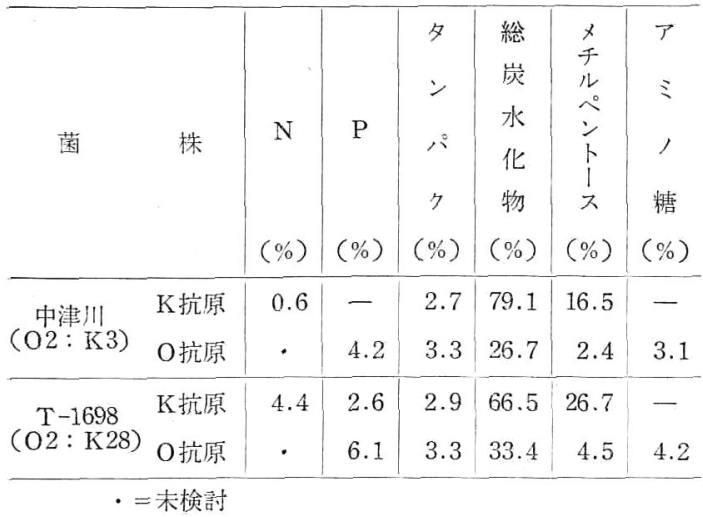

両 K抗原の化学組成は表から明らかなように，窒素， リン含量を除いてほぼ同じ組成を有している。K3 抗原 は炭水化物が $79.1 \%$ ときわめて高いが，タンパクの混 在によると思われるわずかの窒素が認められる。しかし リンおよびアミノ糖は検出されない。アミノ梼の分析に ついては，塩酸による加水分解時間を 2 20 時間の条件 について検討したが，いずれの条件でも陰性であつた。 一方, K 28 抗原も，炭水化物が $66.5 \%$ と高く主体をな しているが，さらにタンパクおよびDNA をかなり含ん でいる。アミノ糖は，K3 抗原同様認められなかつた。 $\mathrm{K} 28$ 抗原はK 3 抗原に比し, 窒素およびリン含量がかな り高いが,これは, K28 抗原が紫外部 $260 \mathrm{~m} \mu$ に吸収を 有すること，さらに核酸 (DNA, RNA) の定量で DNA を含んでいることから，その影響によると思われる。

K抗原と同時に中津川株，およびT-1698 株から抽出 したO抗原の化学組成も女わせて表 1 に示したが，表か ら明らかなように，両菌株由来の○抗原はほぼ同じ組成 より成り， $\mathrm{K}$ 抗原とは，炭水化物，およびアミノ糖の含 量に著しい差が認められた。また，表には示していない が脂質の定性試験では，K抗原が弱陽性であつたのに反 し，O抗原は強陽性を示した。このことは，化学的に $\mathrm{K}$ 抗原とO抗原が明らかに異なることを示している。

以上のように，両 $\mathrm{K}$ 抗原が多糖体の性格を有すること から，つぎにその構成糖をペーパークロマトグラフィー および薄層クロマトグラフィーにより分析した。また， アミノ糖については, さらにアミノ酸アナライザーによ つても検討した。

その結果, 中性糖としてガラクトースおよびラムノー スが，K3 抗原・K28 抗原いずれからも検出された（図 5 )。両 $\mathrm{K}$ 抗原の糖構成の定量比については未検討であ るが，クロマトグラムの発色所見では, 少なくとも両者 の比が異なることが示唆された。アミノ糖は上述の定量

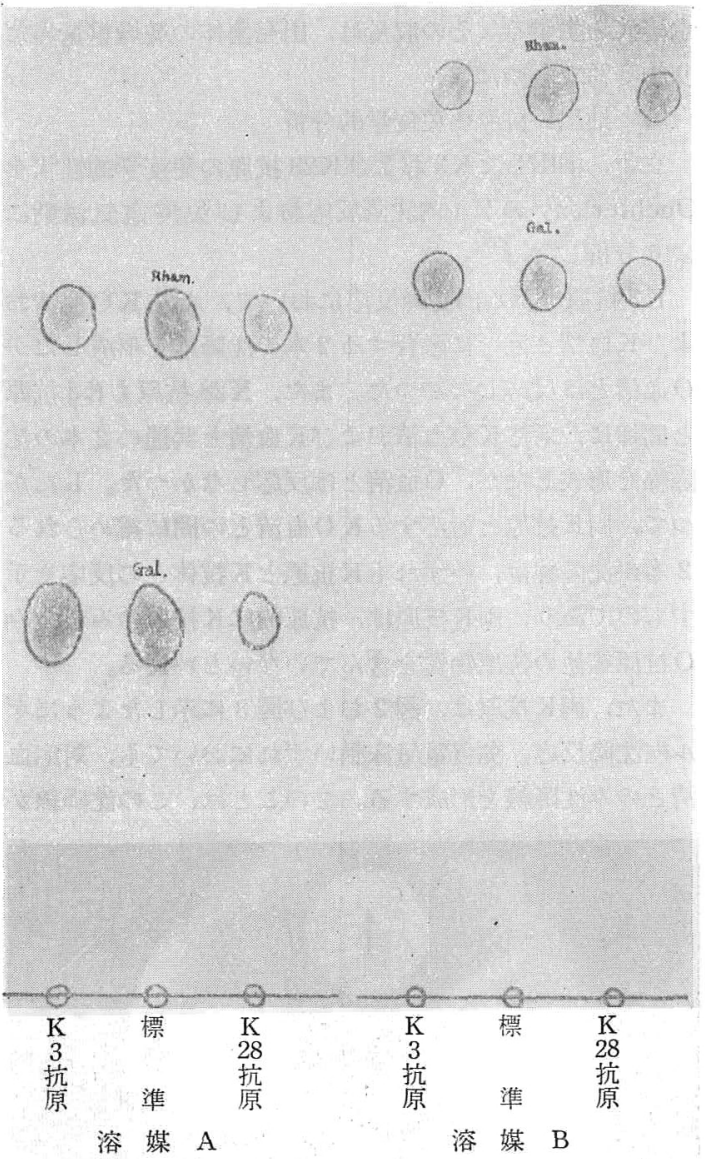

図 5 抽出 $\mathrm{K}$ 抗原のペーパークロマトグラム 東洋濾紙 No. 51, 下降法

溶媒A ピリジン-n-ブタノールー水 $(6: 4: 3)$

溶媒 B ピリジンー酢酸エチルー酶酸一水 $(5: 5: 1: 3)$

成績と同様，ペーパーおよび薄層クロマトグラフィーに よつても検出されなかつた。また，同時に行なつたアミ ノ酸アナライザーの分析においても, 試料 $30 \mathrm{mg}$ の範囲 において,アミノ糖は検出されなかつた。ウロン酸, シ アリン酸, ヘプトース, KDO は定性的に検討したが, 両 K抗原とも試料 $10 \mathrm{mg}$ の範囲において, いずれも陰性で あつた。

\section{5. 抽出 $\mathrm{K}$ 抗原の物理化学的検討}

$\mathrm{K} 3$ およびK28 抗原の均一性を検討するために, まず デンプンを支持体とするゾーン電気泳動による分画を行 なつた。泳動は $\mathrm{pH} 8.3$ 小ウ酸緩衝液の条件で行ない, 泳動後の各プロックの抽出液について, K抗原活性をゲ ル内沈降反応により, 炭水化物をトリプトファン硫酸反 応,核酸を紫外部 $260 \mathrm{~m} \mu$ 吸収によりそれぞれ測定した。 

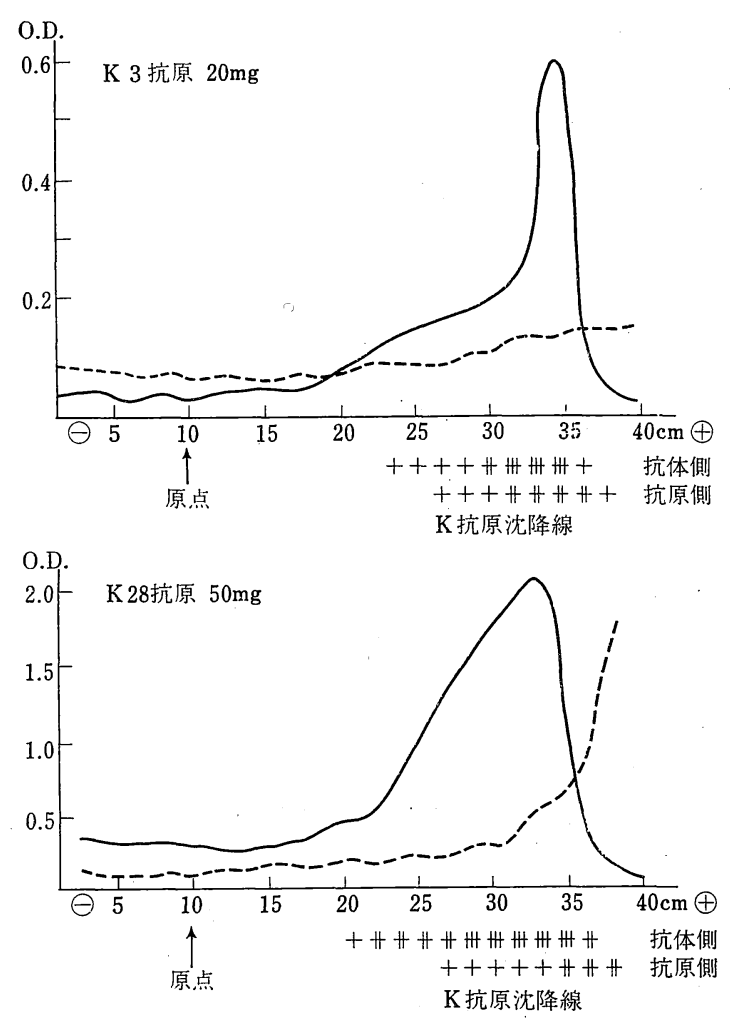

図 6 抽出 $\mathrm{K}$ 抗原のゾーン電気泳動

一全糖（トリプトファン硫酸反応 O.D.549） - - - 核酸（紫外部吸収

O.D.260)

その成績は図 6 に示すとおりである。K3 抗原では, 原点から陽極側 $24 \mathrm{~cm}$ の位置に糖の単一のピークが認 められ, 糖のピークと K 抗原の沈降線の最強部位とはよ く一致した。しかし, 図に K抗原による 2 本の沈降線の 位置を示すように, 両沈降線の態度は, 電気泳動的に異 なることが認められた。すなわち，2本の沈降線のうち 抗体側の沈降線は原点から陽極側 $14 \sim 28 \mathrm{~cm}$ の位置に 認められ，24〜26 cm が最も抗原活性が強いのに反し， 抗原側の沈降線は陽極側 16〜28 cm の位置に認められ， 24〜28 cm に強い活性を示した。

$\mathrm{K} 28$ 抗原では, 原点から陽極側 $22 \mathrm{~cm}$ の位置に糖の ほぼ単一なピークが認められるが，そのピークはK3 抗 原に比しやや幅が広く,また,糖の吸収とはピークを異に するが,なお, 核酸の吸収も認められ, ゾーン電気泳動に よっても，K抗原と核酸を完全に分離することはできな かつた。K抗原の沈降線は, 原点から陽極側 $10 \sim 26 \mathrm{~cm}$ の位置に認められ,糖の反応と一致するが, $260 \mathrm{~m} \mu$ の吸 収ピークは一致しておらず，核酸とは相関していない。
また，本 $\mathrm{K}$ 抗原の場合も $\mathrm{K} 3$ 抗原の場合と同様に，2 本 の沈降線は，電気泳動的に移動度をわずかに異にするこ とが認められた。

以上のように, K3・K 28 両抗原の沈降線は, ゾーン 電気泳動においても免疫電気泳動同様, 陽極側に認めら れるゆえ，両K抗原は酸性物質であるといえる。

つぎに，K3 および $\mathrm{K} 28$ 抗原を，0.1M-酢酸ナトリウ ム溶液に $0.1 \%$ の割合に溶解した試料について，超遠心 分析を行なつた。両 $\mathrm{K}$ 抗原の超遠心像は図 7 に示すよう に, K3 抗原では単一のピークを示し, その沈降定数は $\mathrm{S}_{20 . \mathrm{w}}=5.5$ であつた。しかし，K28 抗原では超遠心的 になお均一でない。主ピークの沈降定数を求めると $\mathrm{S}_{20}$. $\mathrm{w}=3.8$ であつた。

また，両 $\mathrm{K}$ 抗原の赤外吸収分析では，いずれも一 $\mathrm{OH}$. 一 $\mathrm{CH}$ などの吸収を有する, 多糖体特有の吸収スペクト ルを与えた。

6. 抽出 $\mathrm{K}$ 抗原の抗原性（抗体産生能）および致死毒: 性の検討

$\mathrm{K} 3$ 抗原について，抗原性および致死毒性を検討し た。

抗原性 : K3 抗原 $20 \mathrm{mg}$ を, Freund のアジュバント とともにウサギ篮筋に 40 日間にわたり 4 回接種し（総 量 $80 \mathrm{mg}$ ), 対応 $\mathrm{K}$ 抗体の産生の有無を, ゲル内沈降反応 および生菌による凝集反応により調べた。

その結果, 免疫開始後 15 日， 30 日， 45 日，および 60 日のウサギ血清のいずれにおいても，抽出K抗原さのゲ ル内沈降反応, あるいは対応生菌との凝集反応で認めう る抗体は，証明することができなかつた。したがつて， 抽出 K抗原は，ウサギに対して凝集素や沈降素といつた 抗体産生を刺激しないもので, 単に全菌免疫血清によつ て作られるK抗体との反応性だけを有するハプテンであ ると考えられる。

致死毒性：K抗原の $5 \mathrm{mg} \sim 0.156 \mathrm{mg}$ ずつを 1 群 5 頭 のマウス腹腔内に接種して，その致死毒性を検討した。

その成績は表 2 に示すとおりで，K抗原 $5 \mathrm{mg}$ の接種 においても，マウスを致死させることはできなかつた。 また，同時に検討した $\mathrm{O}$ 抗原には強い毒性が認められ， O抗原のマウスに対する LD 50 は， $2.5 \times 2^{-3.375} \mathrm{mg}$ で

表 2 抽出 $\mathrm{K}$ 抗原および $\mathrm{O}$ 抗原のマウス致死毒性

\begin{tabular}{|c|c|c|c|c|c|c|c|c|}
\hline \multirow{2}{*}{\multicolumn{3}{|c|}{$\begin{array}{c}\text { 中津川株 } \\
(\mathrm{O}: \mathrm{K} 3)\end{array}$}} & \multicolumn{6}{|c|}{ 接種量 $(\mathrm{mg})$ 死亡数/接種数 } \\
\hline & & & 5.0 & 2.5 & 1.25 & 0.625 & 0.313 & 0.156 \\
\hline K & 抗 & 原 & $0 / 5$ & $0 / 5$ & $0 / 5$ & $0 / 5$ & $0 / 5$ & $0 / 5$ \\
\hline $\mathrm{O}$ & 抗 & 原 & • & • & $5 / 5$ & $5 / 5$ & $4 / 5$ & $0 / 5$ \\
\hline
\end{tabular}




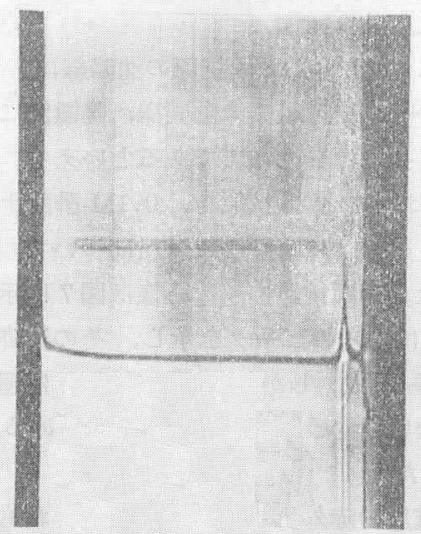

$10 \mathrm{~min}$

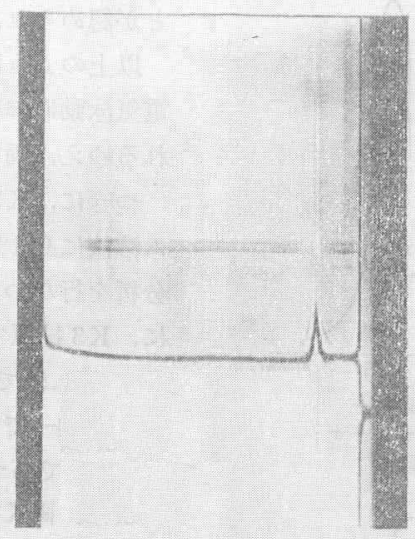

$26 \mathrm{~min}$.

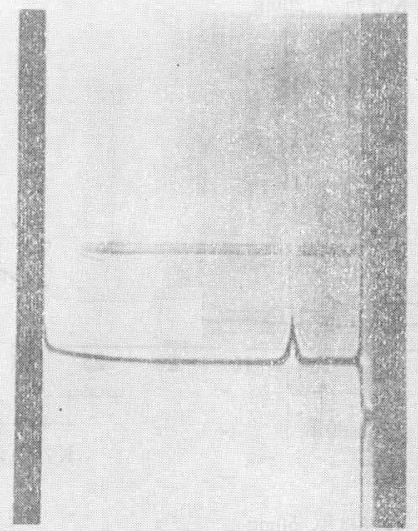

$42 \mathrm{~min}$

K 3 抗原

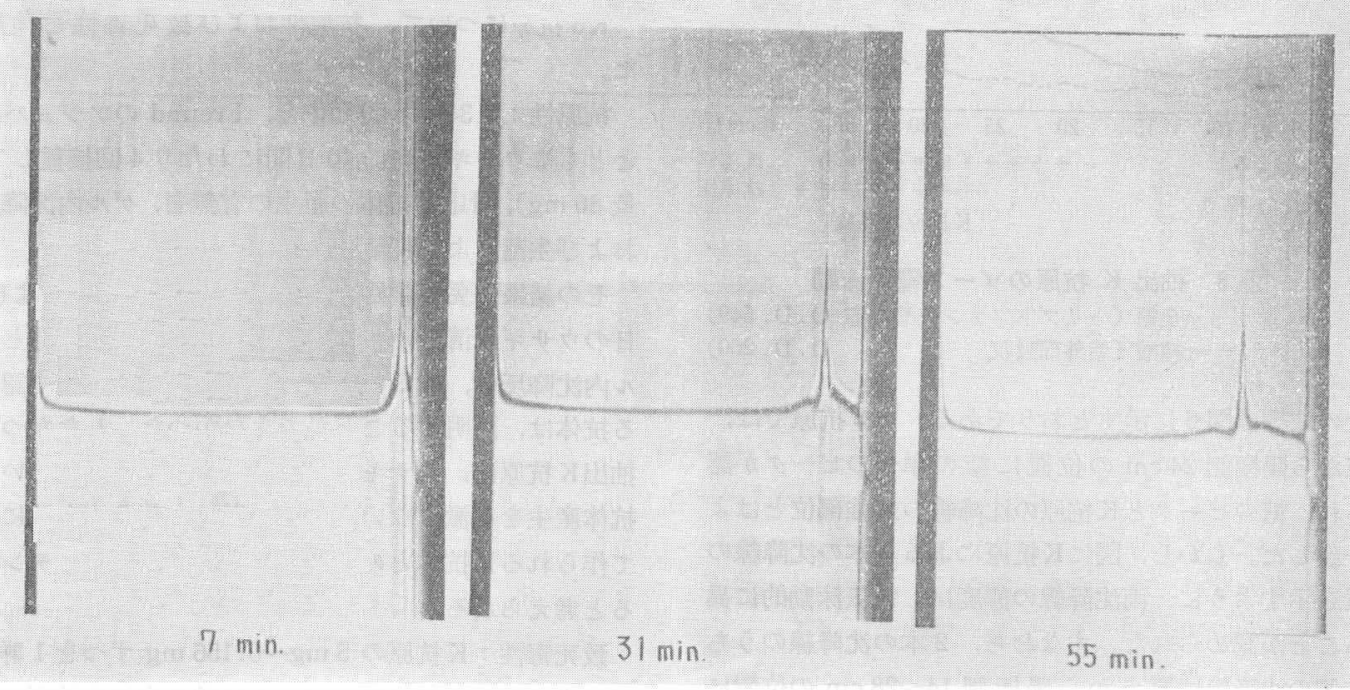

$\mathrm{K} 28$ 抗原

図 7 抽出 $\mathrm{K}$ 抗原の超遠心像

濃度 $0.1 \%$ 溶媒 $0.1 \mathrm{M}$ 酢酸ナトリウム溶液 回転数 55,430 r.p.m.

あつた。

考察

著者らは, 腸炎ビブリオ $\mathrm{K}$ 抗原を, 免疫化学的に明ら かにしたいと考え，まず, O2 群に属するK 3 およびK 28 抗原の抽出・精製を試みた。

既述のよらに, 中津川株 (O2: K3) およびT-1698 株 (O2：K28) の両菌株から, フェノール・水法によ
る抽出, 凍結融解法および超遠心沈殿分画法を用いた精 製法により, 抗原特異性を有すると同時に, きわめて高 い抗原活性を有するK抗原物質を得ることができた。 この抽出K抗原物質は, Omori et al. (1966) によつて 報告された腸炎ビブリオK抗原 (K15), また, Ørskov et al. (1963), Jann et al. $(1965,1966)$, Hungerer et al. (1967) によつて報告された大腸菌K抗原と同様に, 多糖 体を主体とする酸性物質であることが認められた。 
中津川株から得た $\mathrm{K}$ 抗原 (K3) は電気泳動的に, また 超遠心像においてもほぼ均一であることが示されたが， T-1698 株 (K28) 由来のものでは, なおわずかにタンパ クおよび核酸を含み，完全に純粋とはいいがたい。しか しながら，O抗原は，ゲル内沈降反応による抗原分析の うえでは証明されていない。また，化学的にもO抗原に 特異的に認められるアミノ糖が，K抗原に認められない ことは，O抗原を含有していてもきわめてわずかである ことを示している。

しかし，K3 抗原はもちろんのこと，K28抗原もかな り均一な物質であるにもかかわらず，ゲル内沈降反応に おいて，2本の沈降線を形成する。このようなK抗原の 血清学的な不均一性は, Omori et al. (1966) の K15 抗 原，また，一部の大腸菌 $\mathrm{K}$ 抗原 (Jann et al., 1965) に おいても認められているように，2本の沈降線は，いず れもK抗原によるものであろうが，電気泳動的に異なる 態度を示すことは, K抗原をさらに 2 つの成分に分け得 ることを示唆している。また，この 2 本の沈降線は，K 抗原抽出前の生菌液を凍結融解した上清にも認められる ので, 少なくとも抽出操作などによる人工産物とは考え られない。

両抽出 K抗原は, 化学的には多糖体が主体であるが, 同時に両 $\mathrm{K}$ 抗原はわずかのタンパク・脂質を含んでい る。両K抗原の抗原活性は, ゾーン電気泳動などの成績 が示すように，多糖体と密接に関連していることから， 多糖体がK抗原活性に相応しているといえる。しかし， K抗原にわずかに認められるタンパク・脂質が K抗原の 構成分であるか，あるいは単なる不純物であるか否かは なお検討の余地が残されている。

いずれにしても，K抗原の抗原活性，さらに抗原特異 性が多糖体と相関しているゆえ，K抗原の特異性を，そ の構成糖のうえから相互に比較しうることが可能であろ 引。

そこで, 両 $\mathrm{K}$ 抗原多糖体の糖構成についても検討した が, 両 $\mathrm{K}$ 抗原とも同一の糖構成（ガラクトース・ラム） 一ス）であつた。その構成比について定量的に未検討で あるが，クロマトグラムの発色所見から両K抗原の糖構 成比が異なることが示唆された。

Omori et al. (1966) は, K15 抗原が Hexosamine だ けからなり，中性糖を含まないと報告しているのに対し て，K3 およびK28 抗原が，単に中性糖だけからなつて おることから，腸炎ビブリオ $\mathrm{K}$ 抗原の糖構成は，K抗原 型によつて著しく差のあることが推測される。

各K抗原の免疫学的特異性と, 糖構成との関係につい
ては次報で報告する。

\section{結論}

腸炎ビブリオ $\mathrm{K}$ 抗原の免疫学的特異性とその化学構成 を明らかにする目的で, 腸炎ビブリオ中津川株 (O2：K 3), および T-1698株 (O2：K28) からK抗原の抽出・ 精製を試み，以下の成績を得た。

1. 中津川株のカンテン培地培養菌からフェノール・ 水抽出, 凍結融解法および超遠心沈殿分画法によつて, 精製した $\mathrm{K}$ 抗原は，電気泳動，超遠心でほぼ均一の像を 示し，O抗原および核酸の混在は，認められなかつた。

T-1698 株から同様の方法で抽出・精製したK抗原は O抗原を含んでいないが，なお核酸の混在が認められ た。

2. 抽出 $\mathrm{K} 3$ およびK 28 抗原は，ゲル内沈降反応にお いてそれぞれK抗原特異性を示し，両者の間にまつたく 類属関係は，認められなかつた。また，両抽出K抗原は 対応抗 $\mathrm{KO}$ 血清との間にそれぞれ 2 本の沈降線を形成し たが，そのいずれもがK抗原によるものであり，O抗原 等他の抗原物質によるものではなかつた。

3. 抽出 $\mathrm{K}$ 抗原は, 全菌免疫により作成した $\mathrm{K}$ 抗体と 強い反応性を示したが, 抽出 $\mathrm{K}$ 抗原 $80 \mathrm{mg}$ をウサギに接 種しても，K特異抗体の産生は認められなかつた。

4. 抽出 $\mathrm{K}$ 抗原は, マウスに対して $5 \mathrm{mg}$ 腹腔内接種 においても，致死毒性を示さなかつた。

5. 抽出 $\mathrm{K} 3$ および $\mathrm{K} 28$ 抗原は，化学的には多糖体を 主体とする酸性物質であつた。その構成糖は，両者とも ガラクトースおよびラムノースで，酸性の性質を有する にもかかわらず，ウロン酸・シアリン酸等の酸性糖は検 出されなかつた。

終わりに臨み,ご指導およびご校閲を賜わつた善翊寺浩博士， ならびに東邦大学医学部桑原章吾教授に深謝申しげます.

\section{文献}

1) Adachi, S. (1965): J. Chromatog., 17, 295 299.

2) Akashi, S., Goto, H., Sasaki, M., Tsuyama, A., Say, Y. and Kuno, T. (1964) : Nagoya Med. J., 10, 125 146.

3) Ashwell, G. (1957) : Methods in Enzymology, III, pp. 73 104, New York, Academic Press.

4) Belcher, R., Nutten, A.J. and Sambrook, C.M. (1954) : Analyst, 79, $201 \sim 208$.

5) Dische, Z. (1947) : J. Biol. Chem., 171, 725 730.

6) Dische, Z. (1948): J. Biol. Chem., 175, 595 603.

7) Hungerer, D., Jann, K., Jann, B., Фrskov, F. and Фrskov, I. (1967) : European J. Biochem., 2, 115 126.

8) Jann, K., Jann, B., Фrskov, I., Фrskov, F. and West- 
phal, O. (1965) : Biochem. Z., 342, 1 22.

9) Jann, K., Jann, B., Фrskov, I. and Фrskov, F. (1966) : Biochem., Z., 346, 368 385.

10) Kabat, E.A. and Mayer, M.M. (1961 a) : Experimental Immunochemistry, 2nd. Ed., pp. 476 483, Springfield, Charles C. Thomas.

11) Kabat, E.A. and Mayer, M.M. (1961 b) : Experimental Immunochemistry, 2nd. Ed., pp. 551 555, Springfield, Charles C. Thomas.

12）来住輝彦 (1965)：日細誌， 20, 155-161.

13) Lowry, O.H., Rosebrough, N.J., Farr, A.L. and Randall, R.J. (1951) : J. Biol. Chem., 193, 265 275.

14）中村道徳 (1950)：農芸化誌, 24, 1.

15) Okudaira, M., Kawamura, H., Ueno, M., Nakahara, Y., Zen-Yoji, H., Sakai, S., Terayama, T. and Benoki, M. (1962) : Acta Path. Jap., 12, 299 304.

16) Omori, G., Iwao, M., Iida, S. and Kuroda, K. (1966) : Biken J., 9, 33 43.
17) Фrskov, I., Фrskov, F., Jann, B. and Jann, K., (1963) : Nature, 200, 144 146.

18) Osborn, M.J. (1963) : Proc. Nat. Acad. Sci., 50, 499 506.

19) Ouchterlony, Ö. (1949) : Acta path. microbiol. Scand., 26, $507 \sim 515$.

20）坂崎利一（1963）: 腸炎ビブリオ，92-94 頁, 東京, 一成 堂.

21) Scott, J.E. (1960) : Methods of Biochemical Analysis, 8. p. 145 New Yolk, Interscience Publishers, Inc..

22）菅原潔, 副島正美 (1966)：化学と生物, 4, 37-44.

23）滝川嚴, 中橋勇次郎 (1959)：日伝染会誌，33，640-641.

24) Warren, L. (1959) : J. Biol. Chem., 234, 1971 1975.

25) Westphal, O., Lüderitz, O. and Bister, F. (1952) : Z. Naturforsh., 7B, 148.

26) Wiley, B.B.and Sherp, H.E. (1958): Can. J. Microbiol., $4: 505$.

\title{
Studies on $\mathrm{K}$ antigen of Vibrio parahaemolyticus
}

\section{Immunochemical Specificity of $\mathrm{K} 3$ and $\mathrm{K} 28$ Antigens and Their Sugar Constituents}

\author{
Yasuo $\mathrm{KUDOH}$ \\ Department of Bacteriology, Tokyo-to Laboratories for Medical Sciences \\ (Director : Hiroshi ZEN-YOJI, Ph.D.)
}

Studies were made to clarify the immunochemical properties and sugar constituents of $\mathrm{K}$ antigens of Vibro parahaemolyticus. Two strains belonging to the $\mathrm{O}$ group 2, the Nakatsukawa (O $2: \mathrm{K} 3$ ) and the T-1698 (O $2: \mathrm{K} \mathrm{28}$ ), were employed. Purification was made by means of phenol-water extraction, several times of freezing and thawing to remove nucleic acid and ultracentrifugation.

The properties of the $\mathrm{K}$ substances finally obtained were as follows.

1. $\mathrm{K}$ substances showed high degrees of serological specificity when they were subjected to reaction with homologous anti-K sera by the Ouchterlony gel-diffusion method.

2. Contamination with $O$ antigen or any other antigenic substance in these final products were denied by the Ouchterlony method, although the $\mathrm{K}$ substances gave two specific precipitation lines.

3. These two $K$ substances were considered to be a kind of hapten. When rabbits were injected with $80 \mathrm{mg}$ of the substance, no detectable $\mathrm{K}$ antibody was produced in them. Besides, the substances showed no toxic effect on mice.

4. Chemical analyses of these substances revealed that each substance was an acidic polysaccharide which consisted mainly of galactose and rhamnose, and that it contained no trace of such acidic sugars as uronic acid and sialic acid, in spite of the acidic characteristics it exhibited. 